\title{
Super-Diversity and the Prosperous Society
}

\section{NIKOLAY MINTCHEV AND HENRIETTA L. MOORE}

Institute for Global Prosperity, University College London, London, UK

\begin{abstract}
This article asks if and under what conditions ethnic diversity could become a foundation for a prosperous society. Recent studies on ethnic diversity and social cohesion suggest that diversity has a negative effect on social cohesion and therefore is detrimental to the social prosperity of individuals and communities. This paper argues that although such a negative correlation may apply to contexts with well-consolidated ethnic groups, it does not necessarily apply to 'super-diverse' places with multiple small ethnic groups and multiple social, legal, and cultural differences that cut across ethnicity. Drawing on ethnographic material from East London, the authors contend that in super-diverse places ethnic diversity could become a valuable aspect of community life, while inequalities in social, cultural and symbolic capital become central points of social antagonism to the detriment of prosperity.
\end{abstract}

Keywords: prosperity, super-diversity, ethnic identity, inequality, social antagonism, social cohesion, East London.

This article asks if, and under what conditions, ethnic diversity can become the foundation of a prosperous society. Can prosperity be a consequence of diversity and not something that is in conflict with it? What might a diverse prosperous society look like? Recent public debate in Europe has raised the question of whether communities with different cultural traditions can live together without impeding on one another's ability to flourish. This article addresses this issue by considering recent academic work on the topic. In today's world on the move, when millions are displaced by conflict, climate change, and global inequality, it is urgent that we ask if and how, ethnically diverse societies can prosper in ways that are both sustainable and inclusive. How can diverse societies foster what Van Leeuwen calls intercultural citizenship', meaning 'the ability and disposition of citizens to live and work with 
ethnic and cultural others' (2014: 4)? In a 'global city' such as London, which has a long history of migrant settlement, it is no longer sufficient to explain the relationship between diversity and inclusion/exclusion through modes of 'racism' or 'xenophobia' based on skin colour, ethnicity or foreignness. The cultural narratives and legal practices that define who is a stranger are changing. As Back et al. (2012) have argued, there are now 'new hierarchies of belonging' in which race and ethnicity alone no longer define access to citizenship and opportunity. Furthermore, as Joppke (2005) shows, modern day immigration and citizenship policies in 'Western' states are no longer shaped by racial and ethnic exclusion as they were in the past; instead, they are based on an 'individualistic' approach that has little to do with race and ethnicity. What we need, then, is a complex understanding of boundary formation that takes into account the intersections between ethnicity/race and inequalities in economic, social, cultural and symbolic capital. Such an approach is offered by Vertovec's (2007) work on 'super-diversity' - a mode of diversity in which ethnic groups are imbued with multiple internal divisions and inequalities. These inequalities include hierarchical differences between 'old foreigners' and 'new foreigners' (Back et al., 2012: 148), as well as differences of status and resources within groups of 'old' and 'new' migrants. One of the arguments put forth in this paper is that when societies move towards a social model of super-diversity, the lines of division within them become susceptible to change. Drawing on ethnographic data from East London, we show that super-diversity in that area has diminished ethnic tensions and made inequalities far more salient in determining social cohesion and social prosperity. In this regard, the present paper addresses the issue of the respective roles of inequality and ethnic diversity in determining social cohesion and prosperity - an issue that still remains understudied and undertheorized (Demireva, 2015: 4)

\section{Prosperity: A New Category of Social Analysis}

Recent research in economics acknowledges that orthodox economic models which focus on growth are not sustainable in a planet of limited natural resources (Stiglitz et al., 2010; Jackson, 2011; Author, 2015). This demands that we re-purpose the notion of prosperity and focus on new ways to provide opportunities for a socially and culturally fulfilling life. This point is reflected in the recent proliferation of studies on prosperity, happiness, and wellbeing, which offer new metrics of progress, accounting not only for economic wealth, but also for non-economic individual and institutional 
factors (e.g., Huppert et al., 2009; OECD, 2013; Legatum Institute, 2015; Porter and Stern, 2015).

For example, the latest Legatum Prosperity Index (Legatum Institute 2015), defines prosperity through eight different categories: (1) economy, (2) entrepreneurship and opportunity, (3) governance, (4) education (5) health, (6) safety and security, (7) personal freedom, and (8) social capital. Social capital, in this instance is defined as 'social cohesion and engagement, and community and family networks' (2015: 39). Similarly, Richard Layard, in his now famous book Happiness: Lessons from a New Science (2011), argues that an individual's happiness is determined by what he calls the 'big seven' factors (Layard 2011: 62-3): (1) family relationships, (2) financial situation, (3) work, (4) community and friends, (5) health, (6) personal freedom, and (7) personal values.

One problem with this literature, however, is that it consistently fails to take into account immigration, diversity and cultural differences in people's ethical conceptions of a good life. The dimensions of immigration, diversity and culture are important to address because even though the problem of unsustainability is global, the solutions to it must be local and concrete - they must be sensitized to people's specific historical and cultural conceptions of prosperity, happiness, and wellbeing and their transformations (Deneulin and McGregor 2010; Author, 2015). This, furthermore, is linked to an important methodological issue, which is that prosperity cannot be defined a priori, independently of social and cultural realities on the ground. While goals such as sustainability, physical and emotional wellbeing, and high quality of social relationships are integral to any model of prosperity, the meaning of these categories and the pathways through which they can be achieved vary immensely from place to place.

The literature on prosperity, wellbeing and happiness does not sufficiently take diversity into account, but there is now a substantial body of writing, most of it in political science, addressing the impact of ethnic diversity on trust (Branton and Jones, 2005; Putnam, 2007; Stolle et al., 2008; Harrell and Stolle, 2010; Sturgis et al., 2010). This writing is relevant because trust, which is often taken as an indicator for measuring social cohesion (Demireva, 2015), is essential for individual and social flourishing, and it forms a central tenet of wellbeing, happiness and prosperity (Layard 2011: 226; Legatum Institute 2014: 29; 2015: 39). The majority of studies on 
the topic, the most eminent of which is by Robert Putnam (2007), find that diversity is detrimental to trust, both across and within ethnic boundaries. Using data from the US, Putnam examines the correlation between the size of minority groups and the levels of trust in a number of US towns and cities. According to his findings, the more diverse the locale (as indicated by the size of minority groups), the less people trust one another both within and outside of their ethnic group. The presence of minorities leads to competition over resources and cultural hegemony, and this threatens the identity and social status of the majority. As minority groups grow, the threat they pose increases and social trust declines. Consequently, Putnam famously argues, people tend to 'hunker down' in their homes where they watch television alone instead of socializing with friends, neighbours, and others in the community. This process, furthermore, occurs irrespectively of the spatial distribution of ethnic minorities within the community. Putnam controls for spatial distribution of minorities. The reason he gives is that ' $[\mathrm{b}]$ ecause of de facto residential segregation, most Americans' neighbours are of the same race as their own' (2007: 147). Putnam graphs two different correlations to test if spatial segregation makes a difference in patterns of trust. In one figure he shows the relationship between 'Racial Homogeneity and Inter-racial Trust' (2007: 147). In another figure, however, he graphs the correlation between 'Racial Homogeneity and Trust of Neighbours' (2007: 148). His finding is that the two figures show 'virtually the same pattern' (2007: 147). The conclusion that follows from Putnam's work is that ethnic diversity is detrimental for societies because it undermines cohesion, and therefore policy makers should try to curb it by cutting immigration rates (Collier 2014: ch. 5).

Putnam's findings, as some critics point out, are not universally applicable to different places. Instead, the relationship between diversity and social cohesion depends on a number of factors, including the history and ethnic composition of a given community (what kind of people the community is composed of, how they are treated, under what conditions they arrived, etc.) (Harrell and Stolle, 2010: 242; Sturgis et al., 2010: 59, 64). Yet, most studies on the topic, whether they are based on American, Canadian or European data sets, come to the bleak conclusion that diversity has either a negative impact or no impact on trust in others (Branton and Jones, 2005; Stolle et al., 2008; Harrell and Stolle, 2010; Sturgis et al., 2010). Ethnic heterogeneity, as this literature suggests, can hardly be a foundation for a happy and 
prosperous society, at least insofar as trust (as a proxy for social cohesion) is an integral part of a good social life.

In this article we argue that super-diversity is a fundamentally new model of social diversity, in which the relationship between diversity and social relations plays out in a radically different way than that identified by the existing literature. This is not to deny that cultural diversity can be detrimental for social trust, nor that diversity can be more important for community relations in certain circumstances than economic and social inequalities; in fact, below we provide an ethnographic example where ethnicity is the central organizing principle of social conflict. Consequently, this article does not criticize the accuracy of the work of Putnam and others, as much as it attempts to discern if and how the newly emerging model of super-diversity provides alternatives to the correlation that numerous authors identify in older patterns of diversity.

In the current literature, there is one notable exception to the thesis that diversity has negative social consequences. It is the work of Sturgis et al. (2013) on London, where according to the authors, ethnic diversity is positively correlated with trust/social cohesion. This study argues that there is a major difference between the opportunity to come into contact with members of different groups, and the action of coming into contact with them. People in diverse areas who actually interact with others across ethnic divides are more likely to have higher levels of trust than those who do not, as are younger cohorts who are used to living in a mixed environment. Thus, Sturgis and his colleagues conclude that 'ethnic diversity only appears to be problematic for majority white cohorts who grew up with less direct and indirect contact with ethnic minority groups. For younger cohorts, both white and non-white, neighbourhood ethnic diversity is positively associated with social cohesion' (Sturgis et al., 2014: 1304).

In this paper we explore the relationship between ethnic diversity and social cohesion from a different angle. We emphasize that what matters is not only people's changing relationship to ethnic diversity (in this case, the fact that younger cohorts are used to living in mixed environments) but also the changing nature of diversity itself. There is now a growing body of evidence from anthropology and sociology showing that in London older models of diversity are transforming into new configurations of super-diversity - a model comprised of multiple ethnic groups, as well as multiple social boundaries within ethnic groups (Vertovec, 2007; Meissner \& Vertovec, 2015). 
This trend marks a substantial shift in how people experience ethnic difference and community - a shift which may reverse the negative relationship between diversity and prosperity/wellbeing/happiness.

In what follows we examine some of the negative and positive aspects of super-diversity, specifically in relation to trust and cohesion. We then consider various ethnographic data from East London, in order to see if and how different patterns of diversity relate to people's ideas of the prosperous life. We compare a social model comprised of two ethnic groups - what, Susanne Wessendorf (2014a) calls the 'old diversity' - to the more fragmented super-diverse contexts of Hackney and other parts of East London. We conclude that in the context of East London super-diversity marks a significant shift in the configuration of ethnicity and inequality, and a reshaping of prosperity. Ethnic diversity becomes a less salient issue for local residents, and for many it becomes a public good that is valued and actively sought out. Social exclusion, within this context, is no longer based on ethnic prejudice and racism, but rather on economic, social and cultural inequalities. This has important implications for prosperity which must be addressed in future research.

\section{Super-diversity, inequality and class}

Super-diversity is a demographic pattern defined by two key features. Firstly, it involves the growth of migrant communities from different countries of origin. In the UK, multiculturalism has traditionally involved South Asian, African and Carribbean migrants. The past two decades, however, have seen a substantial rise in the number of migrants from Western Europe, Turkey, East Asia, and most recently, Eastern Europe. Secondly, super-diversity is defined by the internal fragmentation of groups which share a common ethnicity or country of origin. This is what Vertovec calls the 'diversification of diversity' on the basis of 'additional variables' that cut across ethnicity. These, according to him, include 'differential immigration statuses and their concomitant entitlements and restrictions of rights, divergent labour market experiences, discrete gender and age profiles, patterns of spatial distribution, and mixed local area responses to service providers and residents' (2007: 1025). Superdiversity is thus about a complexity of intersecting social determinations, not unlike the feminist concept of intersectionality (Berg and Sigona, 2013: 348). The difference, of course, is that while analyses of intersectionality are mainly concerned with gender, sexuality, race, and class, super-diversity - without challenging the 
significance of these four categories - focuses on a different set of determinations. The most notable of these are ethnicity or country of origin and legal status, in addition to class, gender and age (Meissner and Vertovec, 2015: 545).

Super-diversity is thus characterized by a multitude of social boundaries both between and within ethnic groups. At first sight this pattern appears to fit well with the conclusion of Putnam and others that higher diversity reduces trust. After all, super-diverse communities are fragmented to a degree whereby cultural and social difference is ubiquitous. Under such conditions, we would expect that finding common ground and forging social ties with others would be particularly difficult - a hypothesis which is supported by recent ethnographic research. According Susanne Wessendorf's (2014a: ch. 4) work on the London Borough of Hackney, everyday encounters in a super-diverse society often involve lack of knowledge and expectation about who other people are. For her, 'the difficulty of categorizing strangers is what differentiates a super-diverse context from contexts of "old diversity" characterized by the presence of more clearly defined large minority groups' (2014a: 65). This is because the extremely wide variation of cultural identities and individual life trajectories that comprise super-diversity means that any assumption about others would likely be inaccurate. The specific content of cultural otherness remains unpredictable - a mystery which creates social distance, lack of intimacy, and, possibly, also lack of generalized trust.

What is more, the differences in social and cultural capital, and citizenship rights and entitlements that are entrenched in super-diversity cause further distancing and alienation between individuals. Such divisions are not 'horizontal' cultural/ethnic differences, but rather 'vertical' differences that are hierarchically organized; in short, they are inequalities. As recent research shows, one of the many detrimental effects of income inequality is that it creates social distance and lack of empathy (Wilkinson and Pickett, 2010: ch. 4; Dorling, 2014: 140). The larger the distance between those on top and those at the bottom of the economic ladder, the less likely it is that people on each pole will find common ground to trust and empathize with one another, or perceive one another as members of a united community. Put simply: 'In extremely inequitable societies, it can be excruciating even to maintain a conversation across the social divide' (Dorling, 2014: 140).

Inequalities based on citizenship status, cultural capital, availability of social networks, or symbolic position vis-à-vis state ideologies, are closely linked to class 
and can determine one's position in the social class hierarchy. As we know from Bourdieu (1987, 1994), class is a multiply constituted category defined by economic capital and income inequality, as well as by social, cultural and symbolic capital, each of which can be converted into any of the others (see also Savage, 2015; van Hear, 2014: S105). But in addition to being multiply constituted, class is also a category that can slip in and out of relevance depending on the context and the actions of people in it. In 'Symbolic Capital and Social Classes' Bourdieu argues that class operates on two levels - one based on material reality, and another based on the representations of that reality as produced and deployed by social actors.

Social groups, and especially social classes, exist twice...they exist in the objectivity of the first order, that which is recorded by distributions of material properties; and they exist in the objectivity of the second order, that of the contrasted classifications and representations produced by agents on the basis of a practical knowledge of these distributions such as they are expressed in lifestyles. (Bourdieu, 2013 [1978]: 296)

According to Wacquant's (2013) interpretation, this claim means that the existence and relevance of class should not be taken for granted; instead, we should acknowledge that class might become more or less significant in relation to other forms of identity such as ethnicity and gender. For Wacquant, 'the very existence of classes...is not a brute given...Rather, it is the result of...struggles to impose class as the dominant "principle of social vision and division" over and against competing alternatives (such as locality, ethnicity, nationality, gender, age, religion, and so on)' (Wacquant, 2013: 276).

This last point is echoed by Norbert Elias's (2008) classical work on 'the established and the outsider'. There, in a discussion of Marx's theory of class struggle, Elias claims that uneven distribution of the means of production often forms the basis of intergroup conflict, but this is not always the case (2008: 17-20). Social conflict is based on the kinds of 'collective fantasy' (2008: 18) that different groups in society hold about one another, whether they are based on economic inequality, race, religion, or time spent living in a specific neighbourhood. As Elias and Scotson (2008) show in the context of an English town they call Winston Parva, the only 
substantial difference that divided the town's two main groups was that one group had ancestral roots going back numerous generation, while the other group - ethnically, nationally and economically indistinguishable - was made up of newcomers to the town (see also Elias 2008: 3).

In the context of contemporary Britain, however, Bourdieu and Elias' theories that class can slip in and out of relevance has another, additional implication - the fact that class persists in Bourdieu's 'first order' of 'objective' relations, even if its status as 'class' is muted in the second order of classification and expression in lifestyle. Political regimes in Britain since Thatcherism have been persistent in silencing discourses of class, and replacing the notion of class with other categories such as social exclusion, social cohesion, or (lack of) aspiration (Bennett et al., 2009: 2). Within this ideological constellation (and especially during the New Labour governments), class politics was repressed and the working class was violently disenfranchised - a process deemed by some as the 'middle-classification of Britain' (Edwards et al., 2012). Yet at the same time, Britain since Thatcher has also seen a steady rise in inequality and social polarization. This includes growing income inequality, as well as acute symbolic inequality, as indicated by the harsh vilification of those who could not adapt to the new economic policies of deindustrialization (Edwards et al., 2012; Evans, 2012).

It is important to note here that the political exacerbation of class inequality coincided with 'the diversification of diversity' in London. As a result, those who were symbolically and politically excluded by the neo-liberal class politics of Thatcherism and New Labour were not only the white working class, but also asylum seekers, newly arrived immigrants from various regions of the world, and other people whom we discuss in more detail below. This level of complexity makes the standard analysis of social capital used by Putnam and others difficult to apply to the London case, and perhaps even to any case. Putnam's quantitative approach does not consider the link between social capital (as measured by trust, in his case) and symbolic inequality vis-à-vis the circulation of ideological narratives. To his credit, Putnam does ask if income inequality is responsible for lower levels of trust, and concludes that although it is, it is not as important as ethnic diversity. The effects of income inequality, he claims 'are quite parallel to, and independent of, the effects of ethnic diversity' (2009: 156-7) and 'the correlations between social capital and economic inequality are less consistent than those between social capital and ethnic 
diversity' (2009: 157). According to Putnam, the negative relationship between diversity and trust applies equally to more egalitarian and more unequal areas, as well as in richer and poorer neighbourhoods. The problem here is that even though income inequality is of central importance and is rightly addressed, symbolic and other inequalities also play an extremely important role in defining social cohesion, and they have to be taken into consideration.

\section{Is the good life possible in an ethnically diverse society?}

Despite the above arguments that diversity is detrimental to social cohesion, there is a wealth of ethnographic evidence suggesting that super-diversity can in some circumstances contribute to prosperity and wellbeing in a number of ways. While on one level the aforementioned ubiquity of differences may alienate people from one another, on another level it opens up new possibilities for positive attachment to neighbourhood and community. While in places with two or three well-consolidated ethnic groups ethnic difference may be a source of anxiety linked to the threat of persecution, this anxiety is diffused in super-diverse conditions. In a place where everyone is different and no group is large enough or consolidated enough to pose a threat to others, living with difference becomes much easier (Wessendorf, 2014a). As Wessendorf shows, when people are surrounded by difference on a daily basis, civility towards others becomes necessary for getting on in life: 'you cannot afford not to be civil towards people who are different' (2014a: 65). Super-diverse areas become a safe haven in which people can live peacefully and comfortably with their own cultural identity and that of others, while ethnically homogenous areas can be seen as threatening and alienating both for minority ethnic groups and for white Britons surrounded by a single minority (Skey, 2014; Mirza, 2015). Thus, far from causing people to 'hunker down' in the privacy of their homes, super-diversity can offer a safe, yet vibrant, environment for a rich public life (Dines et al. 2006).

In Britain, furthermore, indigenous white people - especially those of 'middle class' background - also tend to see diversity as a desirable attribute of a neighbourhood, and an essential part of living a good life. Reay et al. (2007), for example, show that many white middle-class parents now actively seek an ethnically diverse social and educational environment in which to bring up their children. They argue that in today's cosmopolitan world, being comfortable in a multicultural setting, having knowledge of different cultures, and being able to competently interact with 
other groups are seen as necessary skills for a successful career and a satisfying life. Diversity, for these families, can be a valuable source of cultural and symbolic capital.

We should clarify, however, that this validation of multiculture can often slip into a patronizing stance towards difference and otherness. In fact, Reay and her colleagues take a critical stance towards the middle class white people who actively seek mixed environments, accusing them of exploiting diversity for their own advancement as opposed to investing in it as an end in itself. 'Cultural validation', Reay et al. write, 'is entwined with acquisitive valuing. This is mostly a partial and narcissistic valuing; one that is primarily about recognizing a more colourful self in the ethnic other...' (2007: 1054). Yet, as important as it is to be critical of such narcissistic motives, we should also acknowledge that white middle-class valorization of multiculture can open new avenues for creating a shared prosperity. Individual aspirations and fantasies of the good life are inherently linked to the way people envisage the world and the good society (Author 2011). If this is true, then people cannot treat diversity as a means to an end which is split off and external to diversity itself - they cannot seek a prosperity, whatever that may be, which narrowly focuses on whites, and which just happens to necessitate engagement with cultural difference without incorporating the latter into its vision of the good life. On the contrary, we would argue that the so-called 'cultural omnivores' (Reay et al., 2007: 1046) who gain confidence and satisfaction from their cultural fluency see diversity as an essential attribute of a prosperous society and are deeply invested in it, even if they are sometimes criticized by local working people for not mixing or fitting in.

This last point is confirmed by Butler and Hamnett's (2011) work on class and ethnicity in East London. According to the authors, in East London 'there was a group of white middle-class lower professionals who were committed to living in an area whose mix and diversity they valued and to which they had a commitment to "making it work" (2011: 198). These 'inbound whites', furthermore, 'were reasonably confident in their ability to manage whatever the inner city could throw at them while celebrating its diverse social environments and congratulating themselves for doing so' (2011: 227). Granted, the self-congratulatory element here smacks of a skin-deep engagement with diversity for the selfish aim of gaining liberal and cosmopolitan credentials. However, the fact that people also 'celebrate' diversity and try to 'make it work', suggests that they are ethically committed to it, not only as a means of 
fulfilling their personal aspirations and those of their children, but also because it is a part of their vision of a collective prosperity.

\section{Inequality and The Limits of Super-Diverse Prosperity}

Super-diversity, as the above arguments suggest, can open new paths to constructing and achieving a prosperous life. Yet, as discussed earlier, super-diversity includes multiple cultural differences, as well as various inequalities. These inequalities, unlike ethnic differences, pose a major challenge to cohesion and wellbeing, and they must be redressed by any vision of future prosperity that has super-diversity at its foundations.

There is a fundamental distinction between the axis of multiple ethnic differences that are incorporated into super-diversity, and the axis of economic, social, symbolic and legal inequalities that intersect with ethnicity. Extreme forms of 'horizontal' ethnic diversity can offer a culturally vibrant environment and relative safety from ethnic prejudice, thereby reversing (or at least offsetting) the negative effects that Putnam and others write about. Inequalities, in contrast, cannot undergo such a reversal; widening the gap between rich and poor cannot make a society more socially prosperous, and neither can the proliferation of inequalities of various other forms.

One question that needs to be explored by further research is whether superdiversity transforms the relationship between wellbeing problems linked to ethnic relations and wellbeing problems linked to inequality. There is now strong evidence that subjective wellbeing is impacted negatively by both ethnic/racial prejudice (Priest et al., 2011) and income or class inequality (Wilkinson and Pickett, 2010; Therborn, 2013; Dorling, 2014). Issues ranging from low social trust to high rates of obesity and poor mental health can be the outcome of sustained prejudice as well as inequality. They can also be the outcome of both of these at the same time, such as, for example, when class tensions or competition for resources vis-a-vis a social group coincide with ethnic animosity. But if Wessendorf is correct in arguing that super-diversity reduces prejudice and fosters civility, then the relationship between class inequality and ethnicity must undergo a change as well, especially in deprived inner city areas; if problems of wellbeing persist while diversity increases and community relations improve, then the wellbeing problems in question must become decoupled from diversity and linked more strongly to inequality, deprivation, social and political 
stigma, and unemployment, among other factors. If this hypothesis of decoupling is correct, then the problems of super-diversity can be addressed by policy makers and other actors in a more focused way that specifically acknowledges the salience of inequality and its various forms.

\section{Class and Ethnicity in a Two-Group Community}

At the present moment there is no reliable survey data to indicate if and how the relationship between class/inequality and diversity transforms as diversity increases. There is, however, good ethnographic evidence which suggests that such a transformation occurs and which also outlines its dynamics. In what follows, we detail the changing dynamics of class/inequality and ethnic relations in East London by comparing their intersections in a two-group model and in a super-diverse one. We argue that in a super-diverse context, people become more concerned with inequality and less concerned with ethnic relations, and this points to the emergence of a radically new model of social prosperity in London.

Consider the relationship between ethnicity and class in the London Borough of Tower Hamlets, which for a long time was dominated by white working class residents and Bangladeshi migrants who arrived in the 1960s, 70s and 80s. Historically, as Dench, Gavron and Young (2006) demonstrate in their ethnography, the arrival of people from Bangladesh challenged the economic entitlement of the indigenous working class. For indigenous residents, the post-war welfare state was a reward for their heroic effort and endurance during the Second World War and, specifically, the German bombing campaign in the East End. For them, state benefits and housing did not just reduce inequality and deprivation; they also symbolized the fact that working class people were an integral part of the national community (Dench et al., 2006). These two aspects of post-war life - relative material affluence and respect or recognition at the level of the nation state - were central facets of people's conception and experience of the prosperous life.

However, the arrival of Bangladeshi migrants meant that benefits, jobs and housing now had to be shared with non-British newcomers who had little to do with the war effort and did not live through the bombing of the East End. The frustration became particularly acute after the 1977 Housing Act, which gave housing priority to those with the most urgent needs as opposed to those at the top of the waiting list (Dench et al., 2006: 47-48). This policy allowed large Bangladeshi families in 
desperate need of decent housing to move up the waiting list and receive a council home earlier than indigenous families who had waited for years. Housing, it seemed, was no longer the entitlement of the post-war deserving British working class, but a resource that anyone could claim regardless of what they did for the country. Consequently, as Dench et al. observed during their 1990s fieldwork, in the eyes of white residents 'minorities represent a large and visible part of the something-fornothing society, in which rights to receive support have manifestly overtaken reciprocal obligations to make contributions' (2006: 207). This, of course, was a gross misconception because many migrants worked for years - sometimes decades - in jobs that were poorly paid and detrimental to their health (2006: 207). Nevertheless, migrants were seen as an alien presence in Tower Hamlets, which made little contribution to the economic, social and cultural prosperity of the borough. In this context, Tower Hamlets saw strong ethnic tensions grounded in competition for resources and a string of violent racist attacks which persisted throughout the $70 \mathrm{~s}, 80 \mathrm{~s}$ and 90s (Bethnal Green and Stepney Trades Council, 1978; Cornwell, 1984: ch. 3; Keith, 1995; Dench et al., 2006).

For the white working class, therefore, both class tensions and immigration challenged prosperity in similar ways - they both made access to resources more difficult, and they both devalued the myth of the deserving East Ender who endured the war. On the one hand, the economic and political elite was responsible for deindustrialization and job cuts, and also for failing to protect the entitlement of the deserving post-war working class; on the other hand, immigrants were making claims to jobs, housing and benefits, without having endured the blitz.

This social dynamic fits well with Putnam's argument that 'for various reasons - but, above all, contention over limited resources, diversity fosters out-group distrust and in-group solidarity' (Putnam, 2007: 6). As the ethnographic data show, contention over material entitlements in Tower Hamlets did indeed exacerbate ethnic tensions. What must be emphasized, however, is that it did so within a demographic context of two dominant groups - one of which had recently arrived and challenged the hegemony of the other - and a political and economic context that was already threatening the prosperity of the indigenous working class. Later on, when we turn to super-diversity, we will see that this in-group/out-group distinction is no longer the same, it no-longer overlaps with boundaries between ethnically consolidated groups. 


\section{Class and Ethnicity in a Super-Diverse Context}

In contrast to Tower Hamlets' two-group pattern where problems of class and problems of ethnic relations overlap, the dynamics of super-diversity in Hackney and elsewhere in East London point to a radically different relationship between ethnicity and class. To be sure, these super-diverse contexts are devoid neither of competition for jobs and housing, nor of anti-immigrant sentiments. These issues, in fact, are very much of concern to East End residents living in super-diverse places, but they are differently framed with respect to ethnic difference. Group tensions, social exclusion, and anti-immigrant passions are not organized on the grounds of ethnic differences, but rather on the basis of economic, social and symbolic inequalities.

Studies of class and inequality in East London and elsewhere in Britain point to a pronounced opposition between society and the so-called 'underclass'- a division usually defined by the latter's real or imagined criminality, 'poverty of aspiration', anti-social behavior, or, as in the case of asylum seekers, limited citizenship rights within the UK. The problems of definition and conceptual fuzziness of class categories such as the 'underclass' or 'working class' have been theorized by other authors and cannot be discussed here (Heisler, 1991; Wacquant, 2004). What interests us for the moment is the ethnographic side of the issue - the fact that many communities experience an extreme social divide marked by the presence of a muchfeared marginal group. Butler and Hamnett, for example, claim that in East London 'the relatively advantaged have created a new imaginary of the "urban other"... The fear that this group engenders among many of our respondents cannot be exaggerated, in particular the fear of infecting the carefully nurtured hopes of aspiration for their children' (2011: 23). Or yet again, they tell us that those who wanted to leave the inner city were motivated by the 'risk of being swallowed up by a fear-inducing underclass whose jaws were forever snapping' (2011: 97). Similarly, Reay et al. (2007), whose work we discussed earlier, found that the white valorization of inner city diversity installs a middle class normativity that renders anyone who refuses middle class values 'residualized and positioned as excessive' (2007: 1042). Those who do not or cannot meet the relevant social and cultural standards of conduct are constituted as an 'anti-social', disruptive excess of community and neighbourhood.

The well-known demonized figures in question here are as diverse as they could be: they include the stigmatized, 'feckless' white working-class people, also known as 'chavs', the 'big black thugs', the looters who participated in the 2011 
England riots, and the undocumented migrants and asylum seekers who sleep rough or live in destitute conditions (Reay et al., 2007: 1049; Skeggs, 2004: 23; Jones, 2011; Tyler, 2013). To this list we can further add Muslim radicals who allegedly have no sense of citizenship, low skilled East European 'benefit tourists', and East European Roma who have an infamous history of setting up camps in parks throughout Western Europe. These groups, in the words of Imogen Tyler, are violently portrayed by the media and seen by many as 'a parasitical dysfunctional underclass of failed citizens' (Tyler, 2013: 160).

What then are the implications of today's so-called underclass and the people who are seen as belonging to it? If the aforementioned studies are accurate in their findings, then the cleavage between the underclass and the rest of society constitutes a central point of tension at the level of social relations in super-diverse neighbourhoods and boroughs. Stigma and social exclusion in super-diverse societies can therefore be just as violent as the racism of earlier patterns of diversity. But where super-diversity differs from the two-group model is in the fact that both sides of its social divide are ethnically and socially heterogeneous. Within the public imagination, the 'aspirational', 'law-abiding' majority is comprised of multiple ethnicities, and so is the minority of disadvantaged and marginal people who can be so socially disruptive.

In this context, the fact that many East London residents oppose immigration, as Butler and Hamnett (2011) suggest, is not a symptom of prejudice and racism, nor is it a refusal to share resources and public spaces with people of different ethnicities. Instead, it is an expression of anxiety that newcomers may fail to live up to the normative standards of social conduct, as well as fear that they will make access to affordable housing, decent school places, and public services even more difficult than it already is. Crucially, the division here is one between established residents and newcomers, much as it is in Elias and Scotson's (2008) ethnography mentioned earlier. The difference, however, is that while in Winston Parva, both groups were ethnically and nationally the same, in the context of super-diversity the established and the outsiders are both ethnically diverse. This division overlaps, at least in part, with the inequalities in social, cultural, symbolic and economic capital, that pertain to super-diversity. For it is these kinds of inequalities that are expressed in and through the marginality of all of those who are shunned by the public - gang members hanging on street corners (Gaskell, 2005), 'white working class mums' smoking 
cigarettes outside of school gates (Wessendorf, 2014a: 83), young men looting during riots (The Guardian and LSE, 2011), desperate migrants illegally overcrowding houses (Butler, 2015), and disillusioned young Muslims subscribing to hardline religious doctrines (Gest, 2011).

In this constellation, the narrative of social exclusion of both insiders (the 'underclass') and outsiders (new immigrants), is fundamentally different from that of the classical racism of the 'old diversity'. As Butler and Hamnett point out, social exclusion in modern day East London 'cannot be reduced to the stereotypical immigration-centred caricature of an old, stuffy and xenophobic white working class blaming non-whites for everything, as such views were as prevalent among non-white respondents as among whites' (Butler and Hamnett, 2011: 112). Phil Cohen's observation about immigration in the East London borough of Newham also confirms this point: 'Interestingly, ethnicity made little difference to these responses [about the potential influx of migrants]. Members of BME [Black and Minority Ethnic] communities were as worried about the "immigrant invasion" as were whites' (Cohen, 2013: 315). Finally, a similar argument is put forth by Wessendorf in the context of Hackney. According to her, '[i]n Hackney, the community of the past is always seen as culturally diverse' (2014a: 53). This, she tells us, differs from the nostalgia of white working class residents in Tower Hamlets, for whom the good community of the past was ethnically homogenous (2014a: 53). Wessendorf, however, also explains that imagining both past and present as multicultural does not alleviate fears about immigration:

This does not mean that resentment against newcomers does not exist among long-established residents. According to one of the local councilors I interviewed, these resentments are usually linked to the allocation of housing, and they are not aimed at specific groups. But if people do bring up a narrative about newcomers, it is one in which both the long-established residents as well as the newcomers are imagined as diversified groups which are not defined along clear ethnic lines (Wessendorf, 2014b: 15).

Here, ethnic diversity is not seen as an obstacle to prosperity, as if local problems would disappear if only society could become ethnically homogenous; instead, 
diversity is seen as an integral part of Hackney's social fabric regardless of whether its residents are doing well or not.

If the ethnographic accounts presented above do indeed represent the dominant views of residents in super-diverse East London areas, then what we are seeing is a new configuration of ethnicity and class - one which has important implications for prosperity and wellbeing. The link between experiences of racism and poor wellbeing is well known. Racism, as Harrell puts it 'can traumatize, hurt, humiliate, enrage, confuse, and ultimately prevent optimal growth and functioning of individuals and communities' (2000: 42). Hence, if social exclusion is not defined by ethnicity and race, but by differences in symbolic capital (defined in this case by length of residency) and other inequalities, then we would expect that the challenges of wellbeing and prosperity in a super-diverse society are based more on inequality, and less on racial and ethnic identity. This is despite the fact that such inequalities may be racialized.

As we saw in the example of Tower Hamlets, the challenge to white working class hegemony in the area fostered anxieties similar to those associated with class tension and inequality. In the case of both ethnic relations and class relations, the hard-earned entitlement to benefits, housing and political recognition was threatened and thwarted. In contrast, super-diversity in Hackney and other East End areas, has a different constellation of in-group/out-group dynamics - one which is no longer based on homogenous ethnic groups, but on complex forms of multiply constituted inequalities that cut across ethnicity. Social, emotional and physical problems of wellbeing and prosperity would thus have less to do with ethnicity and cultural difference, and more to do with people's experiences of inequality in relation to others.

\section{Conclusion: Super-Diversity and the Prosperous Society}

So can a multicultural society prosper, and is it possible for ethnic diversity to form a stable bedrock for social prosperity? As Leonie Sandercock astutely observes, social prosperity cannot be achieved in a multicultural context unless diversity becomes integral to its internal organization. As she puts it, 'the good society does not commit itself to a particular vision of the good life and then ask how much diversity it can tolerate within the limits set by this vision' (2006: 49). The good society, instead, must prosper as diverse, not despite being diverse. 
The difference between the 'old' model of two or three groups and superdiversity represents precisely such a shift in people's visions of prosperity. For the white working class in Tower Hamlets, as discussed earlier, the presence of minorities had little to do with prosperity; on the contrary, it was seen as an impediment to the good society. Similarly, notions of prosperity among Bangladeshi migrants something which we were unable to discuss here - were not defined by diversity, but rather by access to material affluence in London and eventual spiritual reunion with the homeland in Bangladesh (Gardner, 2002). This is why many early migrants to the East End upheld 'the myth of return' - the idea that once they earn enough money in Britain they would return to their home villages and build a good life for themselves and their families.

The ethnographic data on super-diversity points to a fundamentally different dynamic of aspiration. To begin with, by definition, super-diversity includes various notions of prosperity and wellbeing, derived from multiple cultural traditions (Author 2015). Secondly, insofar as neighbourhood relations are concerned, a super-diverse context offers, for the most part, a safe environment where people can thrive without fear of everyday racism. Here, pathways to prosperity have little to do with ethnic homogeneity because the social divisions that define everyday life are not organized along ethnic lines, but along other forms of difference - ones based on various inequalities. The latter, as we show, cut across ethnicity so that both sides of the social divide are ethnically heterogeneous.

Within this frame of reference, the prosperous society is no longer imagined as ethnically homogenous with a limited capacity to tolerate difference. Multiculturalism is no longer seen as a concession made by white Britons (see Gardner, 2002: 197), and prosperity is no longer a matter of moving to a less diverse area (white flight) when the threshold for tolerating minorities is exceeded (something which many indigenous people in East London did when immigration transformed the region). Instead, prosperity is much more focused on escaping or redressing deprivation, disadvantage and the 'anti-social behaviour' of all ethnic groups in one's neighbourhood. Ethnic difference is embedded in the social fabric of neighbourhoods from 'top' to 'bottom' and it is equally integral to anxieties about social decline and aspirations for a prosperous future. 


\section{References}

Author (2011)

Author (2015)

Back L, Sinha S, and Bryan C. (2012) New hierarchies of belonging. European Journal of Cultural Studies 15(2): 139-54.

Berg M L and Sigona N. (2013) Ethnography, diversity and urban space. Identities 20(4): 347-60.

Bennett T, Savage M, Silva E, Warde A, Gayo-Cal M and Wright D (2009) Culture, Class, Distinction. London: Routledge.

Bethnal Green and Stepney Trades Council. (1978) Blood on the Street. London: Bethnal Green and Stepney Trades Council.

Bourdieu P (1987) What makes a social class? on the theoretical and practical existence of groups. Berkley Journal of Sociology 32: 1-17.

Bourdieu P (1994) Language and Symbolic Power. Cambridge: Harvard University Press.

Bourdieu P (2013 [1976]) Symbolic capital and social classes. Journal of Classical Sociology 13(2): 292-302.

Branton R and Jones B (2005) Reexamining racial attitudes: the conditional relationship between diversity and socioeconomic environment. American Journal of Political Science 49(2): 359-72.

Butler P (2015) Housing raid finds 26 people living in a three-bedroom East London home. The Guardian. http://www.theguardian.com/society/ 2015/jun/25/overcrowding-housing-raid-26-living-three-bedroom-east-london.

Butler T and Hamnett C (2011) Ethnicity, Class and Aspiration: Understanding London's East End. Portland: Policy Press.

Cohen P (2013) On the Wrong Side of the Track: East London and the Post Olympics. London: Lawrence and Wishart.

Collier P (2014) Exodus: Immigration and Multiculturalism in the 21st Century. London: Penguin.

Cornwell J (1984) Hard-Earned Lives: Accounts of Health and Illness from East London. London: Tavistock.

Demireva N (2015) Immigration, diversity and social cohesion, Oxford: University of Oxford. http://www.migrationobservatory.ox.ac.uk/sites/files/ migobs/Briefing\%20-\%20Immigration\%20Diversity\%20and\%20Social\% 20Cohesion.pdf.

Deneulin S and McGregor J A (2010) The capability approach and the politics of a social conception of wellbeing. European Journal of Social Theory 13(4): 501-19.

Dines N, Cattell V, Gesler W and Curtis S (2006) Public spaces, social relations and well-being in East London. Bristol: Joseph Rowntree Foundation and Policy Press.

Dorling D (2014) Inequality and the 1\%. London: Verso.

Edwards J, Evans G and Smith K (2012) Introduction: the middle class-ification of Britain. Focaal 62: 3-16.

Elias N (2008) Towards a theory of established-outsider relations. In: Wouters C (ed.), The Established and the Outsiders: The Collected Works of Norbert Elias, Volume 4, Dublin: University College Dublin Press, pp. 1-36. 
Elias N and Scotson J (2008) The Established and the Outsiders. In: Wouters C (ed.), The Established and the Outsiders: The Collected Works of Norbert Elias, Volume 4, Dublin: University College Dublin Press, pp. 39-195.

Evans G (2012) 'The aboriginal people of England': the culture of class in contemporary Britain. Focaal 62: 17-29.

Gardner K (2002) Age, Narrative and Migration: The Life Course and Life Histories of Bengali Elders in London. Oxford: Berg.

Gaskell C (2005) 'Fighting For Respect': Youth, Violence and Citizenship in East London. PhD Thesis, London: Queen Mary, University of London.

Gest J (2011) Apart: Alienated and Engaged Muslims in the West. London: Hurst \& Company.

Harell A and Stolle D (2010) Diversity and democratic politics: an introducition. Canadian Journal of Political Science 43(2): 235-56.

Harrell S (2000) A multidimensional conceptualization of racism-related stress: implications for the well-being of people of color. American Journal of Orthopsychiatry 70(1): 42-57.

Heisler B S (1991) A comparative perspective on the underclass: questions of urban poverty, race and citizenship. Theory and Society 11(11): 994-1007.

Huppert F, Marks N, Clark A, Siegrist J, Stutzer A, Vitterso J and Wahrendorf M. (2009) Measuring well-being across Europe: description of the ess well-being module and preliminary findings. Social Indicators Research 91: 301-15.

Jackson T (2011) Prosperity Without Growth: Economics for a Finite Planet. London: Routledge.

Jones O (2011) Chavs: The Demonization of the Working Class. London: Verso.

Joppke C (2005) Exclusion in the liberal state: the case of immigration and citizenship policy. European Journal of Social Theory, 8(1): 43-61.

Keith M (1995) Making the streets visible: placing racial violence in context. New Community 21(4): 551-65.

Layard R (2011) Happiness: Lessons From a New Science. London: Penguin.

Legatum Institute (2014) The 2014 Legatum Prosperity Index. Legatum Institute.http://media.prosperity.com/2014/pdf/publications/PI2014Brochure_ WEB.pdf.

Legatum Institute (2015) The 2015 Legatum Prosperity Index. Legatum Institute. http://www.li.com/activities/publications/2015-legatum-prosperity-index.

Meissner F and Vertovec S (2015) Comparing super-diversity. Ethnic and Racial Studies 38(4): 541-55.

Mirza A (2015) London's super-diversity is a joy. why would you ever want to leave? The Guardian, July 28.

OECD (2013) Measuring Well-Being and Progress. OECD Publishing. http:// www.oecd.org/std/Measuring\%20Well-Being\%20and\%20Progres\% 20Brochure.pdf.

Porter M and Stern S (2015) Social progress index 2015, social progress imperative. http://www.socialprogressimperative.org/publications.

Priest N, Paradies Y, Gunthorpe W, Cairney S, and Sayers S (2011) Racism as a determinant of social and emotional wellbeing for Aboriginal Australian youth. MJA 194(10): 546-50.

Putnam R (2007) E pluribus unum: diversity and community in the twenty-first century. Scandinavian Political Studies 30(2): 137-74.

Reay D, Hollingworth S, Williams K, Crozier G, Jamieson F, David J, and 
Beedell P (2007) 'A darker shade of pale?' Whiteness, the middle classes and multi-ethnic inner city schooling. Sociology 41(6): 1041-60.

Sandercock L (2006) Cosmopolitan urbanism: a love song to our mongrel cities, pp. 37-52 in J. Binnie, J. Holloway, S. Millington, and S. Young (eds)

Cosmopolitan Urbanism. London: Routledge.

Savage M (2015) Social Class in the 21 st Century. London: Pelican.

Skeggs B (2004) Class, Self, Culture. London: Routledge.

Skey M (2014) Tales of one city: London, super-diversity and the paradox of belonging, Open Democracy, May 29. https://www.opendemocracy.net/ ourkingdom/michael-skey/tales-of-one-city-london-superdiversity-andparadox-of-belonging.

Stiglitz J, Sen A, and Fitoussi J-P (2010) Mismeasuring Our Lives: Why GDP Doesn't Always Add Up. New York: New Press.

Stolle D, Soroka S, and Johnston R (2008) When does diversity erode trust? Neighborhood diversity, interpersonal trust and the mediating effect of social interactions. Political Studies 56: 57-75.

Sturgis P, Brunton-Smith I, Read S and Allum N (2011) Does ethnic diversity erode trust? Putnam's 'hunkering down' thesis reconsidered. British Journal of Political Science 41(1): 57-82.

Sturgis P, Brunton-Smith I, Kuha J and Jackson J. (2014) Ethnic diversity, segregation and the social cohesion of neighbourhoods in London. Ethnic and Racial Studies 37(8): 1286-1309.

The Guardian and LSE (2011) Reading the riots: investigating England's summer of disorder. http://eprints.lse.ac.uk/46297/1/Reading\% 20the\%20riots(published).pdf.

Therborn G (2013) The Killing Fields of Inequality. London: Polity.

Tyler I (2013) Revolting Subjects: Social Abjection and Resistance in Neoliberal Britain. London: Zed Books.

Van Hear N (2014) Reconsidering migration and class. International Migration Review 48: S100-121.

Van Leeuwen B (2014) Urban civility or urban community? A false opposition in Richard Sennett's conception of public ethos. European Journal of Social Theory 17(1): 3-23.

Vertovec S (2007) Super-diversity and its implications. Ethnic and Racial Studies 30: $1024-54$.

Wacquant L (2005) Symbolic power in the rule of the 'state nobility', pp. 133-150 in L. Wacquant. (ed) Pierre Bourdieu and Democratic Politics. London: Polity.

Wacquant L (2013) Symbolic power and group-making: on Pierre Bourdieu's reframing of class. Journal of Classical Sociology 13(2): 274-291.

Wacquant L (2014) Decivilizing and demonizing: the social and symbolic remaking of the black ghetto and Elias in the dark ghetto, pp. 95-121 in S. Loyal and S. Quilley (eds) The Sociology of Norbert Elias. Cambridge: Cambridge University Press.

Wessendorf S (2014a) Commonplace Diversity: Social Relations in a Super-Diverse Context. Basingstoke: Palgrave.

Wessendorf S (2014b) researching social relations in super-diverse neighbourhoods: mapping the field. IRiS Working Paper Series 2/2014.

Wilkinson R and Pickett K (2010) The Spirit Level: Why Equality Is Better for 
Everyone. London: Penguin. 